\title{
Contamination of the Internal Handles/Knobs of Public Restroom Doors with Potentially Pathogenic Bacteria
}

\author{
Shawk Fakhoury and Tarek Nawas* \\ Natural Sciences Department, Lebanese American University, Beirut - Lebanon \\ *Corresponding author
}

\begin{tabular}{|l|}
\hline Ke y w o r d s \\
$\begin{array}{l}\text { Door handles, Door } \\
\text { knobs, Public restrooms, } \\
\text { Cross infection, } \\
\text { Contamination potential } \\
\text { pathogens }\end{array}$ \\
\hline Article Info \\
\hline $\begin{array}{l}\text { Accepted: } \\
\text { 26 February } 2018 \\
\text { Available Online: } \\
\text { 10 March } 2018\end{array}$ \\
\hline
\end{tabular}

A B S T R A C T
Microorganisms are present on all surfaces, to which they were carried by many direct and indirect methods of transmission. Regular cleansing of any surface, even using good detergents, will not prohibit organisms from reoccupying these surfaces again and in a very brief period of time. This study aimed at detecting the presence of bacteria on the surfaces of the inside handles/knobs of public restroom doors. Samples collected from doors of 16 public toilets ( 8 for males and 8 for females) were tested for the presence of bacteria. The results showed that almost all the door handles/knobs (93.8\%) were contaminated with potentially pathogenic bacteria. The following organisms were isolated: Staphylococcus aureus (68.8\%), Citrobacter freundii (25\%), Enterobacter cloacae (18.8\%), Rahnellaaquatilis (3.3\%), Shigella sonnei (3.3\%) and Pantoea sp. (3.3\%), indicating that the contamination, most probably, was caused by the hands of the toilet users. It was noted that samples from the males' restrooms were more contaminated than those from the females' restrooms and that door handles carried more organisms than door knobs. These results should alert public toilets' users that extreme caution must be executed while using these toilets, as the internal door handles/knobs, may be a potential source of pathogenic bacteria.

\section{Introduction}

The human hands are important organs of the human body that play a crucialrole in most human movements and activities. Most activities involving the hands impose, however, that they come in contact with many microbes many of which may be potential pathogens.

Although the interference of the normal flora helps in reducing the danger of such encounters, yet the hands, have been proved to carry numerous organisms some of which may be considered dangerous pathogens (Dodrill et al., 2011, University of Wisconsin-Madison, 2016). Organisms including Staphylococcus epidermidis, Staphylococcus hominis, coryneform bacteria (propionibacteria, corynebacteria, dermobacteria), micrococci and few members of the family Enterobacteriaceae were found to be resident bacteria, but many others including Salmonella Typhi, Shigella spp., Escherichia coli, Proteus mirabilis, Citrobacter freundii, Enterobacter spp, Klebsiella spp., Clostridium 
perfringens Staphylococcus aureus, Streptococcus spp., Pseudomonas aeruginosa and other potential pathogens were found to be common transient bacteria (Leyden, et al., 1991; Orskov et al., 1997; WHO, 2009).

Microorganisms are known to be present everywhere. They can be found on dust particles in the air, in water and on all surfaces.

It was, however, demonstrated by many researchers that frequently used surfaces, such as buttons of ATM and vending machines, door handles, computer screens and mice, telephones, library and class desks, are usually more heavily contaminated, with a higher a risk of holding disease-causing microorganisms and thus serve as a means of spreading different types of infections (Reynolds et al., 2005; Hamza and $\mathrm{Na}^{\prime}$ was, 2015, Dakroub and Nawas, 2017).

Previous studies have shown that door handles may be contaminated with different types of microorganisms including Enterococcus feacalis, Coagulase negative staphylococci, Streptococcus spp., Klebsiella spp., Bacillus spp., Escherichia coli, Proteus mirabilis, Proteus vulgaris, Pseudomonas aeruginosa and Staphylococcus aureus (Nworie et al., 2012; Onwubiko and Chinyeaka, 2015).

As many of these organisms are disease causing organisms, the researchers concluded that these door handles play an important role in spreading many diseases.

The purpose of this study was to sample the internal standard door handles and knobs of public restrooms, to detect the presence of potentially pathogenic organisms, considering that these handles and knobs are supposed to have been touched after the restrooms' users have washed their hands and are leaving the facility, to resume their regular activities.

\section{Materials and Methods}

\section{Selection of sampling sites}

Sixteen public restrooms in the RasBeirut area of the Lebanese capital Beirut, were selected for the study. The study was, however, designed to include 8 restrooms for females and 8 for males. In each one of these sets, it was intended to choose 4 restrooms with standard door handles and 4 others with door knobs.

\section{Collection of samples}

Sterile swabs moistened with nutrient broth were used to obtain the samples by scrubbing the selected internal handles/knobs and immersing them in the sterile broth to be transported to the microbiology laboratory, within no more than 30 minutes after collection.

\section{Processing of samples}

In the Microbiology Laboratory, the sample swabs were each cultured the following agar plates: Trypticase soy agar (TSA), MacConkey agar (MA), Mannitol salt agar (MSA), Salmonella-Shigella (SS) agar and Cetrimide agar (CA).

These plates were incubated at $35^{\circ} \mathrm{C}$ and checked for growth after $24 \mathrm{~h}$ and $48 \mathrm{~h}$ of incubation.

\section{Identification of isolates}

The isolates growing on all test plates, were isolated on TSA plates, Gram stained and definitively identified by standard biochemical methods (Cowan and Steel, 1974).

The identity of the isolated Gram-negative bacilli was confirmed using the API 20E test strips (Biomerieux, France). 


\section{Results and Discussion}

The different organisms isolated from the sampled restroom door handles/knobs are shown in Table 1. There was a total of 21 isolates obtained from the 16 sampled restrooms. The frequency of isolation of these organisms from these samples was as follows: Staphylococcus aureus (68.8\%) from 11 samples, Citrobacter freundii (25\%) from 4 samples, Enterobacter cloacae (18.8\%) from 3 samples and Rahnella aquatilis (3.3\%), Shigella sonnei (3.3\%) and Pantoea sp. (3.3\%) each from 1 sample. The 8 standard door handles tested all grew organisms and 4 of the $8(50 \%)$ grew more than one organism, while 7 of the 8 tested door knobs grew organisms with only one of them (12.5\%) growing more than one organism. The frequency of organisms isolated from the males' restrooms was more $(57 \%)$ as compared to that of the organisms isolated from the females' restrooms (43\%).

The isolation of different microbes contaminating door handles/knobs is well documented and noted to serve as possible vehicles for transmission of potentially pathogenic organisms (Rusin et al., 2002; Nworie et al., 2012; Onwubiko and Chinyeaka, 2015). Moreover, Rusin and his colleagues (2002) demonstrated that the numbers of bacteria transferred from the door handles to the hand was very big and that high rates of transfer, of these bacteria, were recorded from the finger tips to the lips

The results of this study, which focused on the internal door handles and knobs of public restrooms, that a person usually uses when leaving the restroom, also demonstrated that a considerable number (93\%) of the tested handles, were contaminated with one or more bacterial strains. This result is very close to the $95 \%$ rate of contamination of fomites, obtained by Otter and French (2009),in
London and very close to the rates of contamination reported by Nworie et al., in 2012(86.7\%) and Onwubiko and Chinyeaka in $2015(86 \%)$ of door handles/knobs in public locations in Nigeria. The observed variations are expected and are related to differences in hygiene and sanitary conditions of the locations tested. Moreover, $31.3 \%$ of the tested handles/knobs grew more than one type of bacterial isolate, a result similar to that previously reported by Rusin et al., (2002) working with hard and nonporous surfaces of fomites and Kennedy et al., (2005) working on refrigerator surfaces.

The results, also, are compatible with the findings of Boone and Gerba (2010), who reported that the levels of contamination of conveniences vary depending on traffic, exposure and environment.

The isolation of more contaminating organisms from the door handles/knobs of the males' restrooms than those of the females' restrooms, in this study, is in contradiction to previous reports (Boone and Gerba, 2010; Nworie et al., 2012; Onwubiko and Chinyeaka, 2015), but can be explained by the fact that one sample from a males' restroom grew 3 organisms, which influenced the rate of isolation of organisms, otherwise the rate would have been very close in both sets of restrooms. Another explanation may be that the females' facilities tested were simply restrooms and not multipurpose ladies' rooms.

A notable observation in this study was that standard door handles were found to be more contaminated than the regular round door knobs. Whereas all door handles tested were contaminated, not all the knob samples grew organisms, as contamination was detected in $87.5 \%$ of the samples. The bigger surface area of the handles, the ease to clean knobs and the way each is held by the hand of the user, may have contributed to this result. 
Table.1 The organisms isolated from the internal door handles and knobs of the public females' and males' restrooms included in this study

\begin{tabular}{|c|c|c|c|}
\hline Sample \# & Restroom for & Shape of handle & Isolates \\
\hline 1 & Females & Handle & $\begin{array}{l}\text { Citrobacter freundii } \\
\text { Staphylococcus aureus }\end{array}$ \\
\hline 2 & Females & Handle & $\begin{array}{l}\text { Citrobacter freundii } \\
\text { Staphylococcus aureus }\end{array}$ \\
\hline 3 & Females & Handle & Staphylococcus aureus \\
\hline 4 & Females & Handle & Staphylococcus aureus \\
\hline 5 & Males & Handle & Staphylococcus aureus \\
\hline 6 & Males & Handle & $\begin{array}{l}\text { Citrobacter freundii } \\
\text { Staphylococcus aureus }\end{array}$ \\
\hline 7 & Males & Handle & $\begin{array}{l}\text { Citrobacter freundii } \\
\text { Staphylococcus aureus }\end{array}$ \\
\hline 8 & Males & Handle & Staphylococcus aureus \\
\hline 9 & Females & Knob & Rahnella aquatilis \\
\hline 10 & Females & Knob & Enterobacter cloacae \\
\hline 11 & Females & Knob & No growth \\
\hline 12 & Females & Knob & Staphylococcus aureus \\
\hline 13 & Males & Knob & Enterobacter cloacae \\
\hline 14 & Males & Knob & Staphylococcus aureus \\
\hline 15 & Males & Knob & Enterobacter cloacae \\
\hline 16 & Males & Knob & $\begin{array}{l}\text { Staphylococcus aureus, } \\
\text { Shigella sonnei, } \\
\text { Pantoea sp3 }\end{array}$ \\
\hline
\end{tabular}

It was, however, previously reported that an interaction of bacteria with metals was possible and that some metals can hold more bacteria than others (Mansfeld, 2007).

The most commonly isolated organism in this study was Staphylococcus aureus, isolated from 11 out of the 16 samples $(68.8 \%)$. This organism is a potentially pathogenic organism that can cause an array of infections ranging from simple abscesses to life threatening infections including pneumonia, endocarditis, meningitis and many others (Tong et al., 2015). Sstaphylococcus aureus was also reported, in other studies, to be the most common contaminant of samples similar to those in this study (Ducel et al., 2002; Brooks et al., 2007; Nworie et al., 2012; Onwubiko and Chinyeaka, 2015), but with a lower rate than ours. Knowing that this organism is a member of the normal flora of the skin and nares of humans, and is easily discharged by several human activities (Cole et al., 2001; Onwubiko and Chinyeaka, 2015), and since the sampling in this study was during the winter months, it is presumed that the higher rate of isolation was either due to increase in nasal discharges or a higher rate of carriage of the organism in the tested population.

All the other isolates, from the different samples of the study, were Gram negative organisms belonging to the family Enterobacteriaceae. Although it was not uncommon to isolate Citrobacter freundii and Enterobacter cloacae (and the closely related 
Pantoea sp. 3) as they were reported to be present on the hands of humans as transient bacteria (Orskov et al., 1997). It was uncommon, however, to isolate Rahnella aquatilis, which is an organism related to fresh water, but can be found in humans and soil (Brenner et al., 1998). The isolation of Shigella sonnei was also unexpected and was indicative of a definite sanitary problem. All these Gram negative organisms have often been reported to be able to cause serious infections and complications of infections and thus are considered as potentially pathogenic organisms (Brenner et al., 1998; Wang et al., 2000; Fraser, 2007; Whalen et al., 2007; Donnenberg, 2015, Mayo clinic staff, 2015). The isolation, in this study, of the above Gran negative organisms, which belong to the family Enterobacteriaceae, may be a strong indicator of fecal contamination of the door handles.

One last observation was, that the sampling was done close to noon time, a time when many of these door handles/knobs were cleaned by the sanitary workers. The persistence of a considerable number of bacteria on these handles and knobs may be interpreted by a number of possibilities: forgetting to clean the internal door handles/knobs because of their location, improper cleaning of these handles and the possibility of using contaminated sponges in the cleaning process, for it was proved that wet sponges can be excellent living places for bacteria since they protect them from exposure to the environment, dry air or sunlight (Samy and Hamdy, 2002) whereby this cleaning is transmitting more germs to the handles/knobs, rather than decreasing them.

These results validate that internal door handles/knobs of public restrooms are an underestimated source of contamination of human hands with potentially pathogenic bacteria and thus a possible cause of self- infection or cross infection to others. Although some measures were introduced to limit this danger, like washing hands properly, drying the hands effectively (Snelling et al., 2011), or even using tissues to hold door handles, yet the danger will still be there. The matter will have to be resolved either by proper design of the doors and or handles/knobs (restrooms with no doors, use of sensor doors or limit the use of regular handles) or by adopting and monitoring more aggressive and frequent cleaning using effective detergents.

\section{References}

Boone, S.A. and Gerba, C.P. 2010. The Prevalence of human parainfluenza virus I on indoor office formite. Food and Environmental virology, 2 (1): 4146.

Brenner, D.J., Muller, H.E., Steigerwalt, A.G., Whitney, A.M., O'Hara, C.M. and Kampfe. P. 1998. Two new Rahnella genomospecies that cannot be phenotypically differentiated from Rahnella aquatilis. International Journal of Systematic Bacteriology 48, 141 149.

Brooks, G. F., Carrol, K. C, Butel, J. S., Morse, S. A. 2007. Jawetz, Melnick, and Adelberg's Medical microbiology. 24th edition. New York: McGraw Hill.

Cole, A. M., Tahk, S., Oren, A., Yoshioka, D., Kim, Y. H., Park, A., Ganz, T. 2001. Determinants of Staphylococcus aureus nasal carriage. ClinDiagn Lab Immunol. 8 (6): 1064-9. doi:10.1128/ CDLI.8.6.1064-1069.2001

Cowan, S.T. and Steel, K.L. 1974. Cowan and Steel manual for the identification of medical bacteria. Cambridge University Press, London.

Dakroub, R. and Nawas, T. 2017. Vending machine buttons and touch screens. A surface colonized by pathogenic 
bacteria. International Journal of Innovative and Applied Research. 5 (5): 82-88.

Dodrill, L., Schmidt, W.P., Cobb, E., Donachie, P., Curtis, V., De-Barra M. 2011. The Effect of Hand washing with Water or Soap on Bacterial Contamination of Hands, International Journal Environmental Public Health Resource, 8(1): 97- 104.

Donnenberg,

$\mathrm{M}$.

2015.

Enterobacteriaceae. Mandell, Douglas, and Bennett's Principles and Practice of Infectious Diseases, 8th Edition. pp. 2503-2517.e5. ISBN 978-1-45574801-3

Ducel, G., Fabry, J. and Nicolle, L. 2002. Prevention of Hospital acquired infection: A practical guide 2nd edition: p. 6.WHO/CDS/CSR/EPH/2002.12

Fraser, S. L. 2007. "Enterobacter Infections." eMedicine. Retrieved from http://www.emedicine.com/med/topic67 8.htm.

Hamzeh, F. and Na'was, T.2015. Computer mice in public centers: A source of pathogenic bacteria. ARPN Journal of Science and Technology. 5 (11): 537539.

Kennedy, J., Jackson, V., Blair, I.S., McDowell, D.A., Cowan, C. and Bolton, D.J. 2005. Food Safety Knowledge of Consumers and the Microbiological and Temperature Status of Their Refrigerators. Journal of Food Protection, 68(7): 1421-1430

Leyden, J., McGinley, K.J., Kaminer, M.S., Bakel, J., Nishijima, S., Grove, M.J. and Grove, G.L. 1991. Computerized image analysis of full hand touch plates: a method for quantification of surface bacteria on hands and the effect of antimicrobial agents. Journal of Hospital Infection, 18 (supplement B): $13-22$
Mansfeld, F. 2007. The interaction of bacteria and metal surfaces. Electrochimica Acta. 52(27): 7670-7680

Mayo Clinic Staff. 2012. "Shigella Infection": Shigella Infection Complications. Mayo Foundation for Medical Education and Research.

Nworie, A., Ayeni, J.A., Eze, U.A. and Azi, S.O. 2012. Bacterial contamination of door handles/knobs in selected public conveniences in Abuja metropolis, Nigeria: a public health threat. Continental Journal of Medical Research, 6 (1): 7 - 11.

Onwubiko, N.E. and Chinyeaka, A.H. 2015. Isolation and identification of bacterial contamination from door handles in a tertiary institution in Umuahia, Abia state, Nigeria. Nigerian Journal of Microbiology.29: 3139-3147.

Otter, J. A., French, G. L. 2009. Bacterial contamination on touch surfaces in the public transport system and in public areas of a hospital in London. Lett App Microbiol 49, 803-805

Reynolds, K.A., Watt, P.M., Boone, S.A., and Gerba, C.P. 2005. Occurrence of Bacteria and Bacteria Markers on Public Surfaces. International Journal of Environmental Health Research, 15(3):225-234

Rusin, P., Maxwell, S. and Gerba, C. 2002. Comparative surface-to-hand and fingertip-to-mouth transfer efficiency of gram-positive bacteria, gram-negative bacteria, and phage. Journal of Applied Microbiology. 93 (4): 585-592

Samy, S.A. and Hamdy, M.E. 2012. Pathogenic Bacteria Associated with different public environmental sites. Journal of Medical Microbiology. 2, 133-137

Snelling, A.M., Saville, T., Stevens, D. and Beggs, C.B. 2011. Comparative evaluation of the hygienic efficacy of an ultra-rapid hand dryer $v s$ conventional 
warm air hand dryers. J ApplMicrobiol. 110(1): 19-26. doi: 10.1111/j.13652672.2010.04838.x

Tong S.Y., Davis, J.S., Eichenberger, E., Holland, T.L. and Fowler, V.G. 2015. Staphylococcus aureus infections: epidemiology, pathophysiology, clinical manifestations, and management". Clinical Microbiology Reviews. 28 (3): 603 661. doi:10.1128/CMR.00134-14

University of Wisconsin-Madison. 2016. Benign bacteria block mosquitoes from transmitting Zika, chikungunya viruses. Science Daily. www.science daily.com/releases/2016/07/160701093 945.htm

Wang J.T., Chang, S.C., Chen, Y.C. and Luh K.T. 2000. Comparison of antimicrobial susceptibility of Citrobacter freundii isolates in two different time periods. The Journal of Microbiology, Immunology and Infection. 33(4): 25862.

Whalen, J.G., Mully, T.W. and Enlgish, J.C. 2007. 3rd. Spontaneous Citrobacter freundii infection in an immune competent patient. Archives of dermatology. 143(1): 124-5.

WHO Guidelines on Hand Hygiene in Health Care: First Global Patient Safety Challenge Clean Care Is Safer Care. Geneva: World Health Organization; 2009. 5, Normal bacterial flora on hands. Available from: https://www. ncbi.nlm.nih.gov/books/NBK144001/

\section{How to cite this article:}

Shawk Fakhoury and Tarek Nawas. 2018. Contamination of the Internal Handles/Knobs of Public Restroom Doors with Potentially Pathogenic Bacteria. Int.J.Curr.Microbiol.App.Sci. 7(03): 3434-3440. doi: https://doi.org/10.20546/ijcmas.2018.703.395 